\title{
JENIS DAN KEPADATAN TUNGAU DEBU RUMAH YANG DITEMUKAN DI KELURAHAN TELING BAWAH KECAMATAN WENANG KOTA MANADO
}

\author{
${ }^{1}$ Yohanes C. W. Kawulur \\ ${ }^{2}$ Josef S. B. Tuda \\ ${ }^{2}$ Greta J. P. Wahongan
}

\author{
${ }^{1}$ Kandidat Skripsi Fakultas Kedokteran Universitas Sam Ratulangi Manado \\ ${ }^{2}$ Bagian Parasitologi Fakultas Kedokteran Universitas Sam Ratulangi Manado \\ Email: yohanes_kawulur@yahoo.com
}

\begin{abstract}
Based on data from district Wenang health centers, there are many known cases of asthma and dermatitis. Asthma and dermatitis can be caused by the presence of dust mites. House dust mites are found in damp houses, mattresses, pillows, bolsters, carpets and many other home furnishings. It highest population was found in the bedroom of dust, especially in mattress dust.. The purpose of this study to determine the species and density of house dust mites in the Teling Bawah Village, District of Wenang Manado City. This research method is descriptive survey with a cross-sectional approach (cross-sectional). Samples were collected from people's homes in the Teling Bawah Village, District of Wenang Manado City then examined in the laboratory of Parasitology, Faculty of Medicine, University of Sam Ratulangi Manado. Results of this study found four species of house dust mites are Dermatophagoides spp, acarus spp, Glycyphagus destrucor spp, and Tarsonemus spp. House dust mite densities obtained an average of 2.21 in the bedroom and 2.13 in the living room. Conclusion: TDR type most commonly found are Dermatophagoides spp and TDR density in the bedroom is higher than in the living room.
\end{abstract}

Keywords: house dust mites, species, density.

\begin{abstract}
Abstrak: Berdasarkan data dari puskesmas Kecamatan Wenang, diketahui banyak terdapat kasus asma dan dermatitis. Asma dan dermatitis bisa diakibatkan oleh keberadaan tungau debu rumah. Tungau debu rumah banyak ditemukan pada rumah yang lembab, kasur, bantal, guling, karpet serta berbagai perabot rumah yang lain. Populasi TDR terbanyak didapatkan pada debu kamar tidur terutama pada debu kasur. Tujuan penelitian ini untuk mengetahui jenis dan kepadatan tungau debu rumah di Kelurahan Teling Bawah Kecamatan Wenang Kota Manado. Metode penelitian ini secara survey deskriptif dengan pendekatan potong lintang (cross sectional). Sampel penelitian dikumpulkan dari rumah-rumah penduduk di Kelurahan Teling Bawah Kecamatan Wenang Kota Manado kemudian diteliti di laboratorium Parasitologi Fakultas Kedokteran, Universitas Sam Ratulangi Manado. Hasil penelitian ini ditemukan 4 jenis tungau debu rumah yaitu Dermatophagoides spp, Acarus spp, Glycyphagus destrucor spp, dan Tarsonemus spp. Kepadatan tungau debu rumah didapatkan rata-rata 2,21 di kamar tidur dan 2,13 di ruang tamu. Simpulan: Jenis TDR yang paling banyak ditemukan yaitu Dermatophagoides spp serta kepadatan TDR di kamar tidur lebih tinggi dibandingkan di ruang tamu.
\end{abstract}

Kata kunci: Tungau debu rumah, jenis, kepadatan.

Debu rumah merupakan partikel yang sering kita jumpai dalam kehidupan sehari-hari. ${ }^{1} \mathrm{Di}$ dalam debu rumah terdapat tungau, karena terdapat bersama debu rumah, maka biasa disebut tungau debu rumah (TDR). ${ }^{2}$ Ukuran tubuh TDR berkisar antara 0,2-0,3 $\mathrm{mm}$ dan 
dibutuhkan setidaknya perbesaran 10X untuk dapat dengan benar mengidentifikasi mereka. ${ }^{1,3}$ Mempunyai kapitalum dan badan berupa kantung, mempunyai empat pasang kaki panjang, dua kedepan dan dua kebelakang. ${ }^{4}$

Tungau bersifat ovipar. Dalam perkembangannnya tungau melalui empat tahapan yaitu telur, larva, nympha, dan bentuk dewasa. ${ }^{1,5}$ Suhu optimal bagi perkembangan populasi TDR adalah $25-30^{\circ} \mathrm{C}$ dan kelembaban relatif $70-80 \%$ dengan kelembapan kritis $60-65 \%{ }^{6,7}$ Perkembangbiakan Tungau Debu Rumah terganggu pada suhu diatas $32^{0} \mathrm{C}$ dan jika tungau dipanaskan selama 6 jam pada suhu $51^{0} \mathrm{C}$ dengan kelembaban udara $60 \%$ maka tungau akan mati. ${ }^{7}$ Populasi dan kepadatan tungau tertinggi terjadi pada bulan-bulan musim panas yang lembab dan terendah di daerah dataran tinggi. ${ }^{3,8}$

TDR banyak ditemukan pada rumah yang lembab, kasur, bantal, guling, karpet serta berbagai perabot rumah yang lain. Populasi TDR terbanyak didapatkan pada debu kamar tidur terutama pada debu kasur. ${ }^{9}$ Dalam satu meter persegi hampir 100.000 tungau debu dapat hidup, dan rata-rata tungau debu tunggal mampu menghasilkan sekitar 20 limbah kotoran setiap hari. Protein, dan kombinasi dari tinja, yang ditemukan di dalam kotoran tersebut yang biasanya menyebabkan reaksi alergi seperti asma, rhinitis, konjungtivitis dan dermatitis atopik pada manusia. ${ }^{10}$

TDR terdapat diseluruh dunia. Berbagai spesies TD terdapat dalam debu rumah,tetapi tungau yang mendominasi adalah famili pyroglyphidae. Di Indonesia, menurut penelitian Aulung (1987) di Jakarta Pusat, telah mengumpulkan 5237 gram debu rumah dari 39 rumah penduduk penderita asma dan alergi debu rumah. Ditemukan 343 tungau. Pada penelitian lanjutannya Aulung melaporkan dari 5411 gram debu rumah diperoleh 876 tungau. ${ }^{6}$

Suhu udara di kota Manado pada siang hari rata-rata $29,4-32,2{ }^{0} \mathrm{C}$ dan pada malam hari $21,6-23,2{ }^{0} \mathrm{C}$. Kelembaban udara berkisar antara $75-92 \% .{ }^{11}$ Kecamatan Wenang merupakan salah satu kecamatan di kota Manado, mempunyai 12 kelurahan dengan jumlah penduduk (Desember 2011) 35.931 jiwa yang terdiri dari laki-laki: 17.825 jiwa dan perempuan 18.016 jiwa. ${ }^{12}$ Teling Bawah yang merupakan salah satu kelurahan dari kecamatan wenang kawasan yang padat penduduk dengan jumlah penduduk sekitar 3.859 jiwa dengan jumlah bangunan rumah sekitar 638 bangunan. ${ }^{13}$ Berdasarkan data dari Puskesmas Kecamatan Wenang, diketahui terdapat 31 kasus penderita asma selama tahun 2012 dan 545 kasus dermatitis selama tahun 2011. ${ }^{14}$

Penelitian TDR di Manado sendiri pernah dilakukan oleh Eri Sudewo Ichsan (2002) di Kecamatan Sario menemukan TDR dengan jenis terbanyak adalah Dermatophagoides spp. ${ }^{15}$ Di Kelurahan Teling Bawah sendiri belum pernah dilakukan penelitian tentang TDR, karena itu peneliti merasa tertarik untuk melakukan penelitian tentang Jenis dan Kepadatan Tungau Debu Rumah yang ditemukan di Kelurahan Teling Bawah Kecamatan Wenang Kota Manado.

\section{METODE}

Penelitian ini dilakukan secara survei deskriptif untuk mendapatkan data tentang jenis dan kepadatan tungau debu rumah. Penelitian ini dilakukan dalam jangka waktu dua bulan yaitu periode NovemberDesember 2012. Sampel yang diambil berupa debu yang dikumpulkan dari kamar tidur dan ruang tamu pada rumah penduduk di Kelurahan Teling Bawah menggunakan metode simple random sampling dengan jumlah rumah yang diperiksa adalah 75 rumah. Pengambilan sampel debu menggunakan vacuum cleaner, Penyedotan debu dilakukan selama 2 menit dengan daerah seluas $1 \mathrm{~m}^{2}$ masing-masing pada ruang keluarga dan ruang tidur. Sampel debu diperiksa di laboratorium bagian Parasitologi Kedokteran Universitas Sam Ratulangi. Identifikasi jenis TDR melalui preparat menggunakan kunci menurut Collof MJ dan Collof MJ et al yang disitasi oleh Ichsan E. ${ }^{15}$ Kepadatan TDR dihitung dari berat debu keseluruhan dibagi 0,1 dan dikali jumlah TDR dalam 0,1 gram debu. 


\section{HASIL PENELITIAN}

Pada penelitian ini ditemukan 4 jenis TDR, pertama tungau debu dengan ciri-ciri relatif besar, setiae (rambut) pada tubuh dengan panjang bervariasi, ujung kaki-kaki (tarsus) pendek diidentifikasi sebagai Dermatophagoides spp. Kedua, tungau debu dengan ciri-ciri bentuknya gemuk dan membulat, pada bagian dorsal terdapat lekuk transversal diidentifikasi sebagai Acarus spp. Tungau debu yang ketiga memiliki ciriciri ujung kaki memanjang, setiae pada tubuh relatif lebih banyak dan lebih panjang, bagian dorsal tanpa lapisan pelindung diidentifikasi sebagai Glycyphagus destrucor. Tungau debu yang keempat memiliki ciriciri ukurannya lebih kecil, kaki IV menebal disertai cakar yang lebar, permukaan dorsal terdiri dari beberapa lapisan yang saling tumpang tindih diidentifikasi sebagai Tarsonemus spp.

Tabel 1. Jumlah tungau debu yang berhasil di temukan dari kamar tidur

\begin{tabular}{ccc}
\hline Jenis Tungau & $\begin{array}{c}\text { Jumlah Tungau } \\
\text { yang berhasil } \\
\text { ditemukan }\end{array}$ & $\mathbf{\%}$ \\
\hline Dermatophagoides spp & 34 & 43,6 \\
Acarus spp & 24 & 30,8 \\
Glycyphagus & 14 & 17,9 \\
destructor & 6 & 7,7 \\
\hline Tarsonemus spp & 78 & 100 \\
\hline Total & &
\end{tabular}

Dari Tabel 1 terlihat bahwa jumlah tungau terbanyak yang berhasil ditemukan dari kamar tidur adalah Dermatophagoides spp.

Tabel 2. Jumlah tungau debu yang berhasil ditemukan dari ruang tamu

\begin{tabular}{ccc}
\hline Jenis Tungau & $\begin{array}{c}\text { Jumlah Tungau } \\
\text { yang berhasil } \\
\text { ditemukan }\end{array}$ & \% \\
\hline Dermatophagoides spp & 30 & 42,8 \\
Acarus spp & 18 & 25,7 \\
Glycyphagus & 13 & 18,5 \\
destructor & 9 & 12,8 \\
\hline Tarsonemus spp & 70 & 100 \\
\hline Total & &
\end{tabular}

Dari Tabel 2, terlihat bahwa jumlah tungau terbanyak yang berhasil ditemukan dari ruang tamu adalah Dermatophagoides spp.

Tabel 3. Kepadatan tungau debu

\begin{tabular}{ccc}
\hline & Kamar Tidur & Ruang Tamu \\
\hline Rata-rata & 2,21 & 2,13 \\
\hline
\end{tabular}

Dari Tabel 3, terlihat bahwa jumlah rata-rata kepadatan tungau debu rumah paling besar ditemukan di kamar tidur.

\section{BAHASAN}

Berdasarkan hasil penelitian ini, didapatkan jumlah dari keseluruhan tungau debu yang berhasil ditemukan di kamar tidur dan ruang tamu. Spesies tungau terbanyak yang berhasil ditemukan dari kamar tidur dan ruang tamu adalah Dermatophagoides spp dimana masing-masing ditemukan sebanyak 34 (43,6\%) dan 30 (42,8\%) tungau (tabel 1 dan tabel 2). Untuk Acarus spp ditemukan sebanyak $24(30,8 \%)$ dan 18 (25,7\%), kemudian Glycyphagus destructor sebanyak 14 (17,9\%) dan 13 (18,5\%), dan yang paling sedikit ditemukan adalah Tarsonemus spp sebanyak $6(7,7 \%)$ dan 9 (12,8\%) tungau (tabel 1 dan 2). Data tersebut sejalan dengan penelitian Eri Sudewo Ichsan (2002) dalam peneletiannya di kecamatan Sario. Spesies tungau debu rumah yang paling banyak dia temukan adalah spesies Dermatophagoides spp. ${ }^{15}$

Dari data dalam penelitian ini diketahui bahwa kamar tidur lebih banyak positif tungau debu dibandingkan ruang tamu. Hal ini mungkin disebabkan karena di kamar tidur terdapat kasur, bantal, karpet dan perabotan lain juga aktivitas kita yang kurang di ruang tamu danlebih banyak di kamar tidur dimana menjadi tempat tungau mendapatkan sumber makanan utamanya berupa serpihan kulit manusia.

Adapun kepadatan TDR yang ditemukan di kamar tidur dan ruang tamu pada 0,1 gram debu adalah 2,21 dan 2,13 
(tabel 3). Data ini lebih rendah dibandingkan penelitian Sukses Hadi (2002), dalam penelitiannya dia menemukan kepadatan TDR dari 0,1 gram debu pada kamar tidur adalah 2,6. ${ }^{16}$

Kota manado yang memeiliki suhu $25^{0} \mathrm{C}-30^{\circ} \mathrm{C}$ dan kelembapan $70-80 \%$ jelas termasuk suhu dan kelembapan yang optimal bagi pertumbuhan tungau sehingga mampu meningkatkan populasi dari tungau debu rumah. ${ }^{11}$

\section{SIMPULAN}

Berdasarkan penelitian ini dapat disimpulkan tungau debu rumah lebih banyak ditemukan pada kamar tidur dibandingkan ruang tamu dengan jenis tungau yang paling banyak adalah Dermatophagoides spp. Kepadatan TDR didapatkan 2,21 di kamar tidur dan 2,13 di ruang tamu.

\section{UCAPAN TERIMA KASIH}

Terima kasih kepada Dr. dr. J. S. B. Tuda, M.Kes, SpPar(K) sebagai dosen pembimbing dan penguji I, dr. G.J.P. Wahongan sebagai dosen pembimbing dan penguji II, dr. J. Runtuwene sebagai penguji III dan kepada semua pihak baik secara langsung atau tidak langsung telah menimbulkan ide untuk penulis sehingga artikel ini terselesaikan.

\section{DAFTAR PUSTAKA}

1. Faiza A. Hubungan antara lama penggunaan kasur kapuk dengan jumlah populasi tungau debu rumah di perumahan PJKA Kelurahan Randusari Semarang [skripsi]. [Semarang]: Universitas Diponegoro; 2006.

2. Natadisastra D, Agoes R. Parasitologi kedokteran ditinjau dari organ tubuh yang diserang. Jakarta: EGC; 2009.
3. Dust Mites: Everything You Might Not Want To Know. Available from : http://www.ehso.com/ehshome/dustmites.ph p.

4. Darwanto.1994.Atlas Parasitologi Kedokteran.Jakarta: Gramedia Pustaka Utama.

5. Yudopranoto K. Perbandingan populasi tungau debu rumah pada kasur kapuk dan non-kapuk di perumahan PJKA Kelurahan Randusari Semarang Selatan Jawa Tengah [skripsi]. [Semarang]: Universitas Diponegoro; 2006.

6. Sungkar,S.Aspek Biomedis Tungau Debu Rumah.Majalah Kedokteran Indonesia; 2004,6(54).

7. Buku ajar parasitologi kedokteran edisi keempat . Staf pengajar Departemen Parasitologi, FKUI,Jakarta. Inge sutanto , Is Suhariah Ismid , Pudji K. Sjarifuddin , Saleha Sungkar.

8. El-Dib, N A.House Dust Mites-What Might A Mite Do?.Medical Science.Vol II.

9. Sujudi Y, Tina W W.Tungau Debu Rumah dan Peranannya Pada Dermatitis Atopik Anak.

10. What are dust mites?. Available from: http://www.dust-mite.net/.

11. Keadaan Iklim. 2012 Januari 28.Available from : http://www.manadokota.go.id/page102-iklim.html

12. Data Penduduk Tahun 2011.Kantor Kecamatan Wenang.

13. Data penduduk. 2012. Kantor Kelurahan Teling Bawah.

14. Data penyakit 2012. Puskesmas Kecamatan Wenang.

15. Eri Sudewo Ichsan. Tungau Debu Rumah yang diisolasi pada rumah penduduk di kelurahan Sario Tumpaan Kecamatan Sario ,Kota Manado periode November 2001Januari 2002 . Universitas Sam Ratulangi.

16. Hadi S. Hubungan kepadatan tungau debu rumah dengan derajat penyakit dermatitis kontak [Tesis]. Semarang: Universitas Diponegoro; 2002. 